\title{
From Socialism to Capitalism: Structural Poverty of Indigenous Women in West Kalimantan, Indonesia
}

\author{
Rupita, ${ }^{1}$ Nikodemus Niko ${ }^{2 *}$ \\ ${ }^{1}$ Departemen Sosiologi, Fakultas Ilmu Sosial dan Ilmu Politik, Universitas \\ Tanjungpura, Pontianak - Indonesia, 2Pascasarjana Sosiologi, Universitas Padjadjaran, \\ Bandung - Indonesia
}

\begin{abstract}
The issue of indigenous women is closely related to the issue of poverty. Women who inhabit rural areas in Indonesia cannot separate from the conditions of life that are poor and completely limited. This paper tries to reflect Karl Marx's thoughts about poverty and injustice that occur in a country because of a structured system. This paper uses a qualitative approach by presenting primary and secondary data. Primary data collection through interviews and field observations, while secondary data through reading readings of scientific studies results in journal articles, policy papers, and government agencies' data. The results of this paper presents: 1) The concept of Marx that poverty is the expression of structural poverty; 2) Poverty among indigenous Dayak Benawan women in rural West Kalimantan, Indonesia, is not only cultural but also structural poverty that expressed limited access to education, health, and a decent standard of quality life; 3) From the era of classical philosophy to modern technology era today, the poverty that has occurred centuries ago today, indigenous women of Dayak Benawan in rural areas are still faced with.
\end{abstract}

Isu perempuan pribumi erat kaitannya dengan isu kemiskinan. Perempuan yang mendiami wilayah-wilayah pedesaan di Indonesia tidak lepas dari kondisi kehidupan yang miskin dan serba terbatas. Makalah ini mencoba untuk merefleksikan pemikiran Karl Mark tentang konsep-konsep kemiskinan dan ketidakadilan yang terjadi dalam suatu negara karena suatu sistem yang terstruktur (memiskinkan). Tulisan ini menggunakan pendekatan kualitatif dengan penyajian data primer dan sekunder. Pengumpulan data primer melalui wawancara dan observasi lapangan, sedangkan data sekunder melalui pengumpulan bacaan hasil penelitian-penelitian ilmiah baik berupa artikel jurnal, surat keputusan maupun data dari instansi pemerintahan. Hasil kajian menemukan bahwa: 1) Menurut Marx kemiskinan yang terjadi adalah kemiskinan struktural; 2) Kemiskinan yang terjadi pada perempuan asli Dayak Benawan di pedesaan Kalimantan Barat, Indonesia tidak hanya kemiskinan kultural tetapi juga terjadi secara struktural, dengan bentuk kemiskinan berupa keterbatasan akses terhadap pendidikan, kesehatan dan standar kualitas hidup layak; 3) Kemiskinan yang telah dialami sejak berabad abad lalu, dari masa filsafat klasik hingga zaman teknologi modern, masih tetap dialami oleh perempuan Dayak Benawan di pedesaan.

Keywords: structural poverty; indigenous women; Marxian; Dayak Benawan

*Corresponding Author: Rupita (rupita_iin@yahoo.com), Jl. Prof. dr. H. Hadari Nawawi, Bansir Laut, Pontianak 78115, Indonesia. 


\section{Introduction}

Poverty in rural areas in Indonesia has become a prolonged issue starting from the end of the 1997 Orde Baru period when national economic conditions deteriorated (Suyanto 2013). Rural poverty is different from poverty in urban areas. Urban poverty is a result of lowskilled, while rural poverty is due to low resources and uneven land ownership in the agricultural sector (Sender 2002; Small and Newman 2001). According to Kumurur (2008), poverty alleviation and eradication are not enough only through anti-poverty programs without accompanied by economic structure changes to ensure the accessibility of women's resources.

It cannot be denied that behind the different disposition groupings of the production activities, there is the power to operate through outsiders' cultural prejudices. Thus, the culture of poverty is introduced to all community members not to realize there is a structural system that deliberately impoverishes them. The poverty that occurs as a result of capitalism is not natural. However, because capitalism itself created it, unemployment and poverty are surplus values for capitalists and must exist to meet the needs of providing cheap labor so that profits remain in the hands of capitalists or the bourgeoisie (Burawoy 2018; Stark 2009).

There is no data on the Central Statistics Agency database that explicitly mentions the poverty of women in Indonesia. Women and children in rural areas are very vulnerable to poverty, such as Cambodia's conflict conditions that cause vulnerability to poverty in women (Ward and Mouyly 2013). Moreover, women in rural areas are far from access to health care, low income, low education, lack of access to assets, and malnutrition (Balagopal 2009).

According to Dao (2009), women in developing countries and working in the agricultural sector have an essential role in poverty reduction. The Sustainable Development Goals (SDGs) agenda targets gender equality and women and girls' empowerment, positively correlated with the ideals to eradicate extreme poverty (Bradshaw, Chant, and Linneker 2017).

In the case of Nigeria, Babatunde et al. (2012) state that the agricultural sector, especially agricultural products, plays a vital role in reducing poverty and inequality. Based on Shiva's (2010) opinion again in the name of development, which expands the modern patriarchal economy. The development itself means the destruction of women, nature, and culture.

A low-income family in a rural area is often able to survive by surviving, both in terms of money and makeshift food. However, in general, families who fall into the poverty cycle are challenging to get back up, except if they have a network or social institutions that protect and save them. Furthermore, this is inseparable from the structural conditions which have kept them in the poverty line.

Nevertheless, by imprisoning the poor on their culture, which is then considered different and judged to be inferior to civilized people's culture, it is tough to imagine that they will quickly escape the shackles of poverty by themselves. The structural system brought them deeper into the abyss of poverty itself. Agusta 
(2014) mentions that a settled settlement pattern and a nuclear family's existence are a new way of perpetuating poverty in modern civilization.

No one community does not crave a prosperous life. Therefore, conditions that indicate a low standard of living are the main targets of improvement efforts to create a prosperous condition. Thus the conditions of life that are not prosperous can be identified as a social problem that must be resolved. It is necessary to find out the underlying factors and understand the conditions, intensity, and complications of poverty. It can find the solution that most can not reduce the quantity, although not entirely eradicated.

Our understanding of the problem of poverty often requires efforts to define and measure. It should be understood that various disciplines have studied the study of poverty. Therefore, it is natural that various poverty concepts and benchmarks are found. Cases of poverty that occur in rural areas are often closely related to the idea of social class, social stratification, and social structure. The poverty that occurs in indigenous tribes in rural areas still occurs not only because of economic problems but structurally curb their lives.

In line with development and globalization, $12,783,505$ people in Indonesia have experienced extreme poverty (World Poverty Clock 2019). Following are the data on Indonesian poverty levels classified by the male and female sex, based on the 2018 Susenas data processed by the national team to accelerate poverty reduction (TNP2K).

Based on Indonesia's poverty situation on the graph, it is illustrated that women's poverty is most vulnerable from 15 to 74 years of age. In contrast, the higher vulnerable groups of women are aged 55 to 85 years and more.

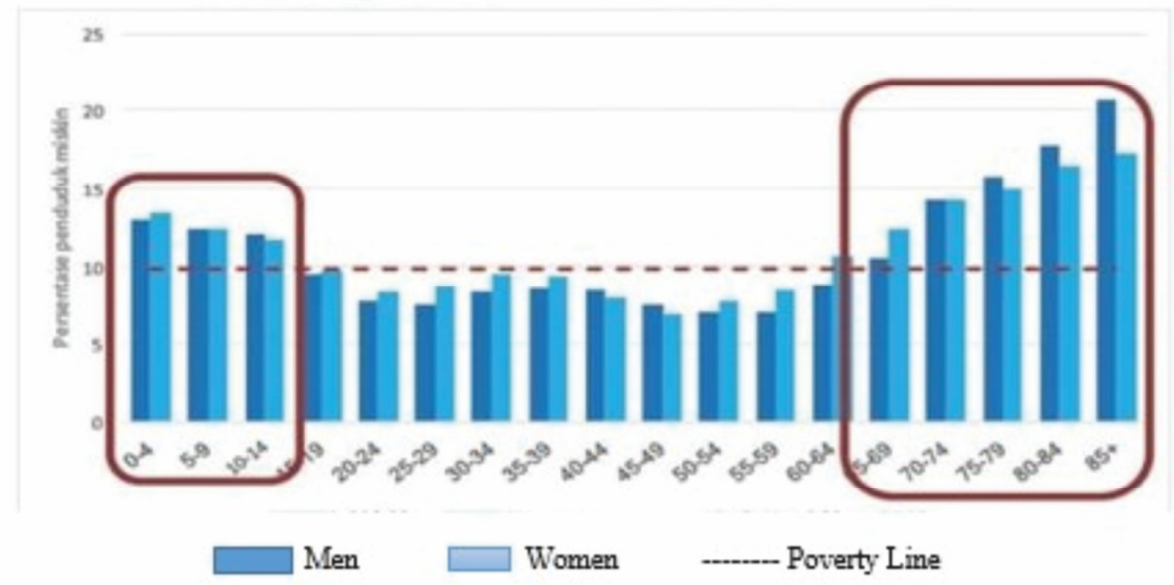

Figure 1. Poverty line gender-based Source: Tim Nasional Percepatan Penanggulangan Kemiskinan (TNP2K) Indonesia, 2019 
The urgency of handling poor women in Indonesia, is especially for indigenous women groups in rural communities. Therefore, this paper aims to: Firstly, discuss the concept of structural poverty in the perspective of Marxism; Secondly, describe the structural poverty experienced by indigenous women in Indonesia; and secondly, analyse the indigenous women poverty by the perspective of Marxism.

In the Indonesian context, the people who inhabit rural areas in West Kalimantan are indigenous groups. The most dominant indigenous tribes are the Dayak ethnic group, which is divided into sub-ethnic groups. In this study, the ethnic groups, which are the object of study, are Dayak Benawan. The Dayak Benawan women's group still lives in poverty, and their lives depend on natural resources (Niko 2018).

Poor women in rural areas work as farm laborers, in practice called odd jobs (Niko 2017). The workers are the proletariat, all of whom have become victims of the exploitation of the bourgeoisie. Marx predicted that class consciousness would occur among the proletariat (Bradshaw 2007; Burawoy 2018). This class consciousness impacts the willingness to carry out the class struggle to escape from exploitation, and this struggle is carried out through revolution.

Along with the development of today's society, the issue of poverty cannot be separated from the issue of women, especially women who live in rural areas. Poverty is the primary tool of oppression for the helplessness of rural women. They have low education and minimal competitive ability (Niko 2019). The quality of human resources possessed is still minimal by the dimensions that oppress them, such as the economic, political, and cultural dimensions. Even poor girls become victims of child marriages (Niko 2016).

Based on statistical data, Fact Sheet No. 22, World Campaign for Human Rights women constitute the majority of the world's poor, and the number of women living in impoverished villages has increased by $50 \%$ since 1975 , women constitute the majority of the illiterate people in the world (Rahayu 2006). Rahmaniah (2014) states that women's economic development in the border villages has not paid much attention to human development.

By comparing the population under the standard based on indicators used in the period before and after the development process, then the success of the process can be seen in the effort to reduce poverty. However, in practice, the reality and the situation is not that simple, especially conditions in rural areas. This paper will explore the structural reasons why indigenous women in rural areas tend to be synonymous with poor living.

In practice, many poverty alleviation programs at the national, regional, and local levels only use an economic approach. Soetomo (2013) states that understanding and handling poverty problems must involve many aspects: the sociological aspect, especially those related to low access to social services, limited social interaction networks, and little mastery of information. In this case, the sociological factors play an essential role in opening the chains of poverty shackles to a not merely economicoriented stage. Other aspects will follow along, such as psychological, economic, and political aspects if this aspect is fulfilled. 
The capitalist system believes that goods are produced to meet the producers' needs and be exchanged in the exchange market. So, each product has a double value, namely the usevalue and exchange value. Every product must have a use-value so that it is able to have an exchange value in the market. With a modern production system, workers can work extra to produce more than their needs and the average working day. Excess production is referred to as surplus value. The surplus or surplus makes additional capital accumulation by the capital owner, and Marx referred to as the extortion level.

\section{Poverty Based on Structures: Karl Marx View}

As the flow of development and globalization continues to progress and develop, millions of people still live below the poverty line. The fact of poverty and inequality is still a problem that has not been resolved to date, especially in Indonesia. In fact, at some level, it gets worse. If poverty is measured by the standard of US $\$ 2$ per day per person, then more than half of Indonesia's population lives below the poverty line (Winarno 2004).

Friedman (2010) defines poverty as an inequality to accumulate a social power base. According to him, what is meant by the social power base includes: first, productive capital for assets, such as housing land, equipment, and health. Second, financial sources, such as adequate income and credit. Third, social and political organizations that can be used to achieve common interests, such as cooperatives. Fourth, a network or social network to obtain jobs, goods, knowledge, and sufficient skills. Fifth, information that is useful for life. This understanding of poverty Friedman proposed he refers to understanding poverty in urban and rural areas.

Suyanto (2001) showed that clove and salt farmers are becoming new poor in rural community. Clove farmers have fallen into poverty due to the clove trade policy's effects, prepared without careful planning. The lack of adequate skills and other sources of income outside the main sectors occupied are the main factors that cause why clove farmers and salt farmers easily collapse and sink into poverty valleys. In this case Marx's remark about rational capitalism holds that the economic mechanism is the commodification of wage labor.

Chamber (1995, 2006, 2015) suggests a broader dimension related to poverty in rural areas. These dimensions are also related to one another in a position to strengthen the conditions of poverty. He also mentions the factors forming the network in poverty traps: poverty itself, physical weakness, isolation, vulnerability, and powerlessness. Thus, being poor is felt to have degraded and is often not the chosen layer. Conditions like this are even realized by the poor themselves, so they define themselves as groups that fail and groups thrown from their social environment.

Poverty is no longer merely economic incapacity and a failure to fulfill fundamental rights and differences in the treatment of a person or group of people in leading a dignified life. The deprivation of these rights is called impoverishment, because fundamental human rights are included the fulfilment of food, health, 
education, employment, housing, clean water, land and natural resources, sense of security, and the right to participate in socio-political life. The deprivation of these rights is called impoverishment (Sameti, Esfahani, and Haghighi 2012; Sherover 1979).

Sociologists often discuss the transition from traditional world systems to modern systems with the concept of differentiation or functional specialization (see: Diamond 2015; Giddens 2005; Gomes and Fishman 1989; Luna 2016; Luxemberg 2003). The shift from a small-scale system to an agrarian civilization and then to modern society can be seen as a progressive process of diversification from within (Giddens 2005). The current globalization brings the system that was traditional to be completely instant. Business companies, especially transnational corporations, can grip economic power and have the capacity to influence political policy. Therefore, poverty and inequality are increasingly sharp between the marginal and the wealthy (Marx 1885).

Globalization has created a space where the state is no longer the only actor in the global political economy. That is a fact that seems to be a recognized truth. Many actors now represent themselves as rulers who surpass the nation's and the world community's ability. The intended actors are multinational companies (MNCs) and multilateral institutions (IMF, World Bank, WTO). Civil movements across national borders (for example, Green Peace) also become other important actors, but not as strong as the two actors mentioned earlier (Winarno 2004). The existence of these actors has reduced state autonomy.
In Marx's view, two classes are always in a conflict where there is a bourgeois class or owner of capital and a working-class. In this case, a class structure describes the "poor" and the "rich." According to Marx (1885), the pursuit of profit is essential in capitalism, with the smallest capital to maximize profit. The extension of the workday and exploitation of labor is one of the methods used by capitalists to pursue a surplus that can increase capital. Employers are forced to reduce the cost of production.

The above conditions are referred to by Marx (1885) as pauperization or immiseration. It meant the relative disparity that continualy grow between working class and capitalist class. Meanwhile the capitalist class continued to hoard wealth, the wages of the workers never met their need, so they will always live-in poverty. Working-class/ proletarian poverty is defined as a condition of poverty that is not natural poverty caused by a lack of resources but is a result of industrial production's contemporary organization, which means poverty occurs structurally (Parthasarathy 2015; Peet 1975; Stark 2009).

Poverty as a social phenomenon is experienced by developing countries and occurs in countries with a stable economy. This phenomenon has become a global concern, issue, and human movement. Poverty is no longer seen merely as an economic problem or lack of food, clothing, and shelter. However, it shows an increasingly complex problem.

The existence of a structure ingrained in this system, according to Marx, will then cause suffering and exploitation for the small farmers. Another dimension that needs to be considered 
is the depth and severity of poverty. Rural communities are the primary workers in agriculture. Therefore, many poor farmers are in rural areas. Marx's opinion in 1847, that:

"In the agricultural industry the price of products obtained with the largest amount of work that regulates the prices of all products of the same type. First of all, as in the manufacturing industry, one cannot multiply the means of production with the same degree of productivity, that is, land plots with the same degree of fertility. Then, as the population grows, lower quality land begins to be exploited, or capital expenditures, which are proportionally more expensive, certainly get prices like a plot of land that is exploited cheaper." (Marx 2007).

Marx's view, which explicitly describes a general pattern of peasant societies that is inferior, and the competition develops actively among the capitalists has produced at a level of their desires, without thinking of the peasants. In Indonesian context, it is only natural to say, "yang kaya makin kaya, yang miskin makin miskin (the rich will be getting richer, and the poor still struggle with their poverty)." Agricultural exploitation must be subjected to a giant industrial regime and ultimately solely aimed at enriching the conglomerates.

The method used in this study is descriptive exploratory, where the source of data comes from primary data and secondary data. The characteristics of this type of qualitative research can be seen with this type of approach, emphasizing the exploration, explanation, and description of knowledge in an ethical, emic, and holistic manner. Primary data was obtained through interviews and the opinions of actors. This study's secondary data was obtained by searching scientific papers such as journals and books related to the research theme.
This is a fieldwork research, so it applies some data collection methods: observation, interview, participatory observation, and documentation. We interviewed five Dayak Benawan women, with the following criteria: (a) comes from the indigenous family of Dayak Benawan (indigenous); (b) low-income family (under 2 US \$ per day).

\section{Poverty on Indigenous Women of Dayak Benawan}

The Dayak Benawan tribe is one of the Dayak sub-tribes who live in several rural areas in Balai District, Sanggau Regency, West Kalimantan, Indonesia. The Dayak Benawan people live in groups in village areas. There are more than 1,000 people of indigenous Dayak Benawan who live in Cowet Village. The Dayak Benawan community in Cowet Village has the main livelihood as shifting cultivators (kume'k) and rubber tappers (motong' $k$ ).

A small portion of the Dayak Benawan women in Cowet Village completed their education up to elementary school, and most of them did not receive higher education. There are no junior high schools and senior high schools in the village. Secondary schools are only located in the subdistrict capital, which is about 4.5 kilometers away by passing through forests and villages. The reason for not going to the secondary school factually not only the distance of the school from their surrounding, but also the school fee.

In community development today, the issue of poverty can not be separated from the issue of women, especially women who live in rural areas. Poverty is the primary tool of oppression for the helplessness of rural women. They have 
low education and minimal competitiveness. The quality of human resources possessed is still minimal by the dimensions that oppress them, such as the economic, political, and cultural dimensions.

In the community of Cowet Village, there are still poor households. Village government data in 2015 noted that 118 household heads were still on the poverty line, out of a total of 362 households. Dayak Benawan women are a vulnerable group in their community, and this can be seen in the application of customary law in the Dayak Benawan community, which is still dominated by men's decisions. So that customary rules cannot be avoided if it directly targets women.

The poverty that occurs in Dayak Benawan women is the lack of accessibility to the economy, education and land mastery. Cowet Village office records show that the villagers' poverty is still high, which is about $33 \%$ of the kepala keluarga is still poor. It means that women in low-income families are experiencing poverty.

The backwardness of rural communities inhabiting rural areas is not new; there have been many studies that have tried to find solutions to overcome these problems (See: Diamond 2015; Santoso 2018), even the poor's resistance movement and oppressed (Crawshaw and Jackson 2015). Nevertheless, this backwardness still shackles inland communities that seem to have no way out. This deteriorating condition of the society marked by the high rate of poverty, high illiteracy, and surrender to fate.

When poverty is considered as a 'poor' culture in rural communities, it is no longer visible where inequality and injustice are. Though it is clear that inequality and injustice befall almost all women who live in rural areas. However, it cannot be denied that behind the different disposition groupings of production or capitalism activities, the power operates through the development of cultural prejudices developed by outsiders.

In the Dayak Benawan community, women only have voting rights but do not have authority in decision making both within the family and outside it (Niko 2018). The decision, in any case, still rests on men. Therefore, poverty experienced is structural poverty that starts at the family level. The Dayak group's marginalization began in the New Order era, where the Dayak community did not have strategic positions in government (Tanasaldy 2012).

The bodies of women who experience exploitation in various periods of Indonesian history, including those who experience poverty, trafficking, and the imposition of cultural and religious traditions, are trapped (Arivia 2011). Thus the culture of poverty is introduced to all community members not to realize a structural system that deliberately impoverishes them.

The issue of women's poverty, especially women in rural area, is important to be expressed because it involves social and cultural value, beside it is related to human right. Himat (2015) emphasized that the substance of CEDAW (Convention on Elimination of All Forms of Discrimination Against Women) is to stipulate that women have civil, political, economic, social, and cultural rights, which must be enjoyed on an equal basis with men regardless of marital status.

Poverty alleviation in rural areas is a national development agenda and an international development agenda that has been designed. According to Shiva (2010), the national elite's 
development agenda to exploit in the context of national interests is a colonialist colonialism style. According to the colonial concept, to grow, capitalists must have a colony so that capital can be easily collected (Luxemberg 2003).

A low-income family in rural areas can often live with limitations; they survive, both in money and food. Women are the backbone of their families. However, in general, a family that falls into a cycle of poverty is complicated to get back up, except if it has a network or social institutions that protect and save them. Furthermore, this condition is inseparable from the structural conditions which have kept them from staying in poverty. So that women come to bear the poverty that bound their families.

One indicator contributing to the impact of poverty on rural women is education. Education level is an important indicator of women's social capital to achieve a better standard of living. However, Dayak Benawan women's education level on average does not finish junior high school. Data from Cowet Village office records that there are only two womens who finished school at the S1 level (Sarjana) and one woman who finished school in the D3 level (Diploma Tiga). There are about $90 \%$ of Dayak Benawan women who do not end their education in elementary school. This low education's impact is that they lack the knowledge and skills to create a better living atmosphere.

\section{From Socialism to Capitalism: Poverty of Indigenous Women}

The poverty that occurs in Dayak Benawan women is full of definitions of capitalism, where poverty is defined as a lack of income and lack of money. The poverty experienced by the proletariat has made them aware of their misfortune from the capitalist system. The lives of indigenous tribes in the countryside are not loaded with wealth, and they take natural resources following the needs of daily life. Seeing the conditions of the workers in the system of capitalism, Marx wants a new system in the system of society, namely, socialism, where there is no private property (private property) of the bourgeoisie, there shared or communal ownership (Sherover 1979).

Socialism marked by the workers' revolution will abolish private property's right to the means of production, so there is no longer exploitation by one class against another class, in this case, the exploitation of the capitalists against the proletariat. The "poor" are then allowed to change their destiny for the better, even though it is going very slowly and takes a long time.

In socialism, the economic system is subsistence, that is, production is only to fulfill the living needs of members of the community and not to stack as the capital as in the capitalist system. In the Dayak Benawan tribal community who live by planting, they produce food for each family's needs. They never sell food from agricultural products out of their community. If there are families with abundant harvests, they sell with a barter system.

Based on interviews and observations we conducted on dayak benawan indigenous people in ancient times (about 30 years ago), the group's strength was built through royong'k where food barns were created for all community members. Then, they also built joint ownership such as vegetable gardens and orchards that they called kompong'k. Besides, they are farming by growing rice for the fulfillment of community food. 
The indigenous community of Dayak Benawan survives with their community because of a sense of belonging between individuals and groups. So, they do not define themselves poor. To realize this, according to Marx, the working class must unite and carry out a revolution, just as the bourgeoisie/capitalists make a revolution against the feudal lords. Because the revolution itself consists of two stages, first, when the bourgeois revolution against the feudal lords, the second revolution is the revolution of the workers against the bourgeoisie/capitalists.

Socialists view the capitalist system as an unjust and irrational system, which should be abolished. Many consequences are caused, including an epidemic of poverty that is increasingly afflicting developing countries. Moreover, even today, the phenomenon of poverty is still widespread in developing countries such as Indonesia. However, Marx disagreed, and he criticized the early socialists because they did not view capitalism in a historical context. Fink (2010) criticized Marx because Marx capitalism has ended feudal injustice and irrationality. But capitalism has replaced it with its injustice and irrationality.

The state efforts to assist in improving the welfare of low-income families and social protection for poor children in rural areas include efforts to develop productive activities and empowerment for low-income families to get their basic rights. There is an opening in the constitution, which explicitly states that public welfare is every citizen's right. In this case, the state is the key to poverty alleviation, and the poor in this country are the responsibility of the state.
Poverty is ingrained in the lives of indigenous Dayak Benawan women. Therefore, it is not uncommon for them to get exploitation treatment in the labor sector and even become victims of a capitalist economy. Poor indigenous tribal women marginalized many times because; 1) they are a marginalized indigenous tribe; 2 ) they are women who's marginalized; 3) because they are weak and powerless. The state is still not present amid their lives, which incidentally is still isolated.

Marx said that civil society would be threatened by a crisis if left alone. This statement does contain multiple interpretations, and it means that civil society (the poor) if there is an omission by the state, there will be a crisis. The crisis in question can be in the form of a humanitarian crisis such as hunger, plague, war, and various other social problems. On the other hand, Hegel argues that the state can and must guarantee the public interest rather than competing particular interests in society, thus preventing the system's risks.

In the Dayak Benawan community, the government provides agricultural assistance facilities that can help increase the result of harvests. On the other hand, the government through West Kalimantan Governor Regulation number 19 of 2020 on the prevention and control of forest and land, which prohibits clearing land by burning. Meanwhile, Dayak Benawan community opened the field by burning. So there is their fear and anxiety to grow.

Development policies and poverty alleviation programs that are developed often do not pay less attention to the poor's characteristics and local contexts so that many policies then become 
'project' land for a handful of elite elements. In Dayak Benawan community there is already a package of poverty reduction policies such as providing food and cash direct assistance to lowincome families, but specifically program that empowers women's economies has nothing. Marx remark which states is an instrument of the ruling class, although the state seems to be a neutral mediator among competing interests.

Marx's presupposes that it is imperative to examine the forces operating in contemporary society. It means Marx is very supportive and must have a preliminary study to understand the local context's community. It is ironic if the state disburses many funds and programs to the poor without first considering the social structure in local communities, which incidentally is patterned and stratified on various dimensions.

It is a failure once the empowerment program is carried out by setting up supermarkets like Indomaret and Alfamart in villages with a low educational level population. It will result in the faded of the traditional economic system that existed a long time before. It means that making the village a center of modern trade is the development of poverty alleviation that is more captured. Because what happens is profitable for the capitalist.

\section{Conclusion}

The indigenous women of the Dayak Benawan poverty problem occur in a structured way and will not stand alone, so handling the problem also demands understanding and scrutiny. The lack of access to economy, education and land ownership is the cause of poverty in Dayak Benawan women. Meanwhile, poverty alleviation policies do not target the Dayak Benawan community's needs, such as modern market development and modern agricultural development. Teaching them to farm in a modern way is also not a solution to poverty alleviation in the Dayak Benawan community. So far, they have survived with food products managed in their traditional way and local knowledge. As a result, they remain in sustainable poor.]

\section{References}

Adetunji Babatunde, M., Olugboyega A. Oyeranti, Abiodun S. Bankole, and E. Olawale Ogunkola. 2012. "Exports Trade, Employment and Poverty Reduction in Nigeria." International Journal of Social Economics 39(11): 875-99. doi: 10.1108/ 03068291211263916.

Agusta, Ivanovich. 2014. Diskursus, Kekuasaan, dan Praktik Kemiskinan di Pedesaan. Jakarta: Yayasan Obor Indonesia.

Arivia, Gadis. 2011. "Merebut Kembali Kendali Tubuh Perempuan." Jurnal Perempuan 71:85-107.

Balagopal, Gayathri. 2009. "Access to Health Care among Poor Elderly Women in India: How Far Do Policies Respond to Women's Realities?" Gender \& Development 17(3): 481-91. doi: 10.1080/ 13552070903298543.

Bradshaw, Sarah, Sylvia Chant, and Brian Linneker. 2017. "Gender and Poverty: What We Know, Don't Know, and Need to Know for Agenda 2030." Gender, Place \& Culture 24(12):1667-88. doi: 10.1080/0966369X. 2017.1395821.

Bradshaw, Ted K. 2007. "Theories of Poverty and Anti-Poverty Programs in Community Development." Community Development 
38(1): $\quad 7-25 . \quad$ doi: $\quad 10.1080 /$ 15575330709490182.

Burawoy, Michael. 2018. "The Poverty of Philosophy" edited by T. Medvetz and J. J. Sallaz. Retrieved (http://oxfordhandbooks. com/view/10.1093/oxfordhb/978019935 7192.001.0001/oxfordhb9780199357192-e-16).

Chambers, Robert. 1995. "Poverty and Livelihoods: Whose Reality Counts?" Environment and Urbanization 7(1):173-204. doi: 10.1177/095624789500700106.

Chambers, Robert. 2006. Poverty Unperceived: Traps, Biases and Agenda. Institute of Develpment Studies, University of Sussex, Brighton UK.

Chambers, Robert. 2015. "Participation, Pluralism and Perceptions of Poverty." Pp. 140-64 in The Many Dimensions of Poverty, edited by N. Kakwani and J. Silber. London: Palgrave Macmillan UK.

Crawshaw, Steve, and John Jackson. 2015. Tindakan-Tindakan Kecil Perlawanan: Bagaimana Keberanian, Ketegaran, dan Kecerdikan Dapat Mengubah Dunia. Yogyakarta: Insist Press.

Diamond, Jared. 2015. The World until Yesterday: Apa yang Dapat Kita Pelajari dari Masyarakat Tradisional? Jakarta: Gramedia Pustaka Utama.

Fink, Hans. 2010. Filsafat Sosial: Dari Feodal hingga Pasar Bebas. Yogyakarta: Pustaka Pelajar.

Friedmann, John. 2010. "Rethinking Poverty: Empowerment and Citizen Rights." International Social Science Journal 48(148): 161-72. doi: 10.1111/j.14682451.1996. tb00070.x.

Giddens, Anthony. 2005. Konsekuensi-Konsekuensi Modernitas. Yogyakarta: Kreasi Wacana.

Gomes, Ralph C., and Waida Katz Fishman. 1989. "A Critique of The Truly Disadvantaged: A
Historical Materialist (Marxist) Perspective." The Journal of Sociology \& Social Welfare 16(4):77-98.

Himat, Makia. G. A. 2015. "Sociological Approach to the Convention on the Elimination of All Forms of Discrimination against Women (CEDAW) (Critical - Comparative Study)." International Journal of Gender and Women's Studies 3(2): 120-37. doi: 10.15640/ijgws.v3n2a11.

Kumurur, Veronica Adelin, Meutia Farida Swasono, and Budhy Tjahjati S. Soegijoko. 2008. "Kondisi Kemiskinan Perempuan dalam Pembangunan Kota: Kajian tentang Kehidupan Perempuan Miskin dalam Pembangunan Kota Jakarta Tahun 20012007." Program Pascasarjana Universitas Indonesia.

Luna, Victor Manuel Isidro. 2016. "The Persistence of Poverty in Capitalist Countries." Economía Informa 400: 67-82. doi: 10.1016/j.ecin.2016.09.005.

Luxemberg, Rosa. 2003. The Accumulation of Capital. London: Routledge and Kegan Paul.

Marx, Karl. 1885. The Poverty of Phylosophy. Moscow: Foreign Language Publishing House.

Marx, Karl. 2007. Kemiskinan Filsafat [Karl Marx (1847)]. Bogor: Hasta Mitra.

Niko, Nikodemus. 2016. "Poor Girls are Vulnerable to be Married: A Case Study of Dayak Mali Law in West Kalimantan." Jurnal Perempuan 21(1). doi: 10.34309/ jp.v21i1.8.

Niko, Nikodemus. 2017. "Women in Poverty; A Case Study on Dayak Mali Ethnic of West Kalimantan, Indonesia." International Journal of Humanities, Religion and Social Science 1(1):8-10.

Niko, Nikodemus. 2018. Perempuan Dayak Benawan: Kedudukan pada Sturktur Domestik \& Publik. Yogyakarta: Deepublish. 
Niko, Nikodemus. 2019. "Kemiskinan Perempuan Dayak Benawan di Kalimantan Barat sebagai Bentuk Kolonialisme Baru." Jurnal Pemikiran Sosiologi 6(1):58-76. doi: 10.22146/jps.v6i1.47467.

Parthasarathy, D. 2015. "The Poverty of (Marxist) Theory: Peasant Classes, Provincial Capital, and the Critique of Globalization in India." Journal of Social History 48(4):816-41. doi: 10.1093/jsh/shv044.

Peet, Richard. 1975. "Inequality and Poverty: A Marxist-Geographic Theory." Annals of the Association of American Geographers 65 (4):564-71. doi: 10.1111/j.1467-8306. 1975.tb01063.x.

Quang Dao, Minh. 2009. "Poverty, Income Distribution, and Agriculture in Developing Countries." Journal of Economic Studies 36(2): 168-83. doi: 10.1108/ 01443580910955051.

Rahayu, Salma Safitri. 2006. “Analisis Rancangan Undang-Undang Pemberantasan Tindak Pidana Perdagangan Orang." Jurnal Perempuan (49).

Rahmaniah, Syarifah Ema. 2014. Model Pembangunan Perbatasan Berbasis Kearifan Lokal. Pontianak: STAIN Pontianak Press.

Sameti, M., Rahim Dallali Esfahani, and H. Haghighi. 2012. "Theories of Poverty: A Comparative Analysis." Arabian Journal of Business and Management Review 1(6):4556.

Santoso, D. 2018. Penduduk Miskin Transient: Masalah Kemiskinan yang Terabaikan. Jakarta: Yayasan Obor Indonesia.

Sender, John. 2002. "Women's Struggle to Escape Rural Poverty in South Africa." Journal of Agrarian Change 2(1): 1-49. doi: 10.1111/ 1471-0366.00023.

Sherover, Erica. 1979. "The Virtue of Poverty: Marx's Transformation of Hegel's Concept of the Poor." Canadian Journal of Political and Social Theory 3(1):53-66.

Shiva, Vandana. 2010. "Staying Alive: Women, Ecology and Survival in India [Book Review]." The Journal of Australian Political Economy.

Small, Mario Luis, and Katherine Newman. 2001. "Urban Poverty after The Truly Disadvantaged: The Rediscovery of the Family, the Neighborhood, and Culture." Annual Review of Sociology 27(1):23-45. doi: 10.1146/annurev.soc.27.1.23.

Soetomo, Soetomo. 2013. Masalah Sosial dan Upaya Pemecahannya. Yogyakarta: Pustaka Pelajar.

Stark, Barbara. 2009. "Theories of Poverty/The Poverty of Theory." Brigham Young University Law Review 381-425.

Suyanto, Bagong. 2001. "Kemiskinan dan Pemberdayaan Masyarakat Miskin." Masyarakat, Kebudayaan dan Politik14(4):25-42.

Suyanto, Bagong. 2013. Anatomi Kemiskinan dan Strategi Penanganannya. Malang: Intrans Publishing.

Tanasaldy, Taufiq. 2012. Regime Change and Ethnic Politics in Indonesia: Dayak Politics of West Kalimantan. Leiden: KITLV Press Leiden.

Ward, Kristy, and Vichhra Mouyly. 2013. "The Importance of Being Connected: Urban Poor Women's Experience of Self-Help Discourse in Cambodia." Gender \& Development 21(2):313-26. doi: 10.1080/ 13552074.2013.802482.

Winarno, B. 2004. Dinamika Isu-Isu Global Kontemporer. Yogyakarta: CAPS.

World Poverty Clock. 2019. "Federal Ministry for Economic Cooperation and Development." Retrieved (https://worldpoverty.io/index. html). 
The page was intentionally left blank. 